\title{
Using the ERT method in tectonically active areas: hints from Southern Apennine (Italy)
}

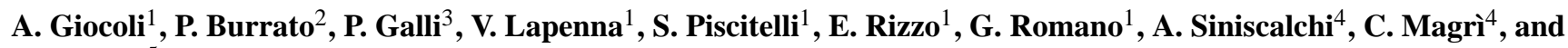 \\ P. Vannoli ${ }^{5}$ \\ ${ }^{1}$ Istituto di Metodologie per l'Analisi Ambientale - CNR - Tito (PZ), Italy \\ ${ }^{2}$ Istituto Nazionale di Geofisica e Vulcanologia - Rome, Italy \\ ${ }^{3}$ Dipartimento della Protezione Civile, Rome, Italy \\ ${ }^{4}$ Dipartimento di Geologia e Geofisica, Università di Bari, Bari, Italy \\ ${ }^{5}$ Istituto Nazionale di Geofisica e Vulcanologia - Grottaminarda (AV), Italy
}

Received: 27 July 2008 - Revised: 3 September 2008 - Accepted: 5 September 2008 - Published: 14 November 2008

\begin{abstract}
Electrical Resistivity Tomography (ERT) method has been used to study two tectonically active areas of southern Apennine (Caggiano Faults and Ufita Basin). The main aim of this job was to study the structural setting of the investigated areas, i.e. the geometry of the basins at depth, the location of active faults at surface, and their geometrical characterization. The comparison between ERT and trench/drilling data allowed us to evaluate the efficacy of the ERT method in studying active faults and the structural setting of seismogenic areas.

In the Timpa del Vento intermontane basin, high resolution ERT across the Caggiano Fault scarps, with different arrays, electrode spacing (from 1 to $10 \mathrm{~m}$ ) and penetration depth (from about 5 to $40 \mathrm{~m}$ ) was carried out. The obtained resistivity models allowed us to locate the fault planes along the hillslope and to gather information at depth, as later confirmed by paleoseismological trenches excavated across the fault trace.

In the Ufita River Valley a 3560-m-long ERT was carried out across the basin, joining 11 roll-along multi-channel acquisition system with an electrode spacing of $20 \mathrm{~m}$ and reaching an investigation depth of about $170 \mathrm{~m}$. The ERT allowed us to reconstruct the geometry and thickness of the Quaternary deposits filling the Ufita Valley. Our reconstruction of the depositional setting is in agreement with an interpretative geological section based on borehole data.
\end{abstract}

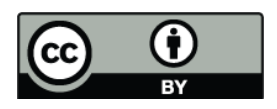

Correspondence to: A. Giocoli

(giocoli@imaa.cnr.it)

\section{Introduction}

Numerous case studies exist aimed at the improving of the knowledge of seismogenic areas by using geophysical exploration. In particular, the electrical resistivity tomography method (ERT) is a quick, non-invasive and low-cost geophysical method widely applied to obtain 2-D or 3-D highresolution imaging of the resistivity subsurface pattern. ERT has been shown to be a useful method in a wide class of geological problems: i.e., to determine the location of active faults at surface and to quantify displacements in Quaternary formations before performing trenching paleoseismological studies (e.g. Storz et al., 2000; Suzuki et al., 2000; Demanet et al., 2001; Caputo et al., 2003; Nguyen et al., 2003, 2005; Wise et al., 2003; Galli et al., 2006), to infer some characteristics of the fault zones, such as the presence of fluids, and to estimate the width of the damage zone (Diaferia et al., 2006), to study the structural setting of geological sedimentary basins (Rizzo et al., 2004).

This paper presents the results obtained using the ERT during the investigation of one strand of the Caggiano Fault (Galli et al., 2006; Timpa del Vento segment), and the deep geological setting of the Ufita River Valley. The ERT investigations were aimed to (1) detecting and pinpointing the fault location, (2) delineating the internal structure of the fault zone (3) estimating the cumulative displacement and (4) imaging the deep geological setting. In both cases a comparison between ERT models and geological evidence from trenching or drilling data was done.

Published by Copernicus Publications on behalf of the European Geosciences Union. 


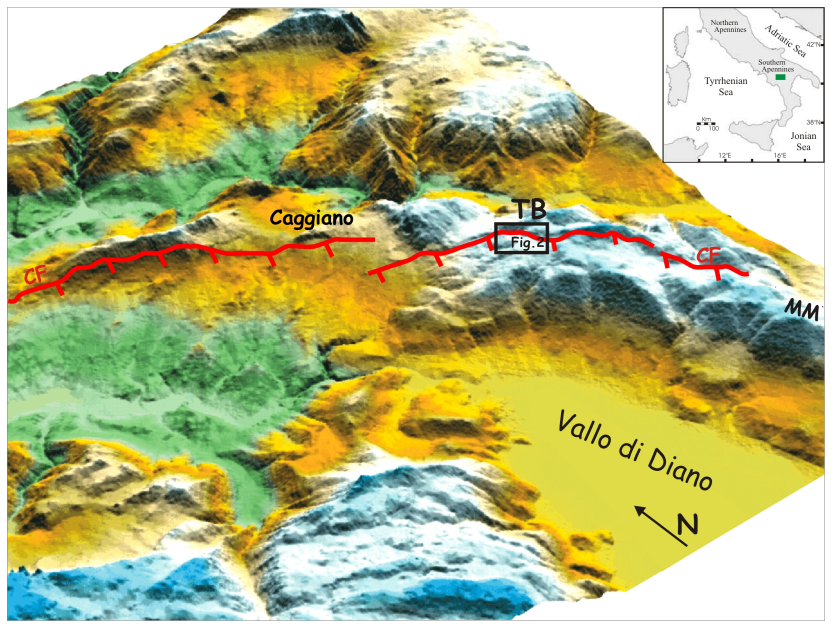

Fig. 1. Map of the Caggiano normal fault system (CF). (MM) Northern sector of the Maddalena Mts; TB, Timpa del Vento intermontane basin.

\section{ERT surveys}

ERT surveys were carried out by means of a georesistivimeter Syscal R2 (Iris Instruments), coupled with a multielectrode system, using different array configurations (WennerSchlumberger and Dipole-Dipole) and electrode spacing, obtaining different investigation depth. Apparent resistivity data were inverted using the RES2DINV software (Loke, 2001) to obtain high resolution resistivity images of subsurface. The 2-D inversion routine applies a Gauss-Newton least squares method (Loke and Barker, 1996), based on the finitedifference model of the subsurface, automatically adjusted in an iterative process. The latest is obtained comparing the measured apparent resistivities and the calculated apparent resistivities obtained from inverted resistivity model. The Root Mean Squared (RMS) error provides a measurement of this difference as an indicator of the goodness of fit. Furthermore, in the cases of sharp resistivity contrast a 11-norm inversion method (robust) is applied. This method minimizes the absolute (Abs) difference between the measured and calculated apparent resistivity values.

\subsection{Caggiano Fault (Timpa del Vento basin)}

The small Timpa del Vento intermontane basin is located in the axial part of the Campania-Lucania sector of the Southern Apennines (Italy) on the northern sector of the Maddalena Mounts. The latter are a range which extend from NW to SE over $50 \mathrm{~km}$, separating the Vallo di Diano Quaternary intermontane basin to the west from the high Agri River Valley to the east. This area has been struck by two disruptive earthquakes in 1561 and 1857 (Galli et al., 2006). Paleoseismological analyses carried out on the Maddalena Mounts indicate repeated post LGM ruptures along the 17-km-long, N120 normal fault system (Caggiano Fault - CF), which is

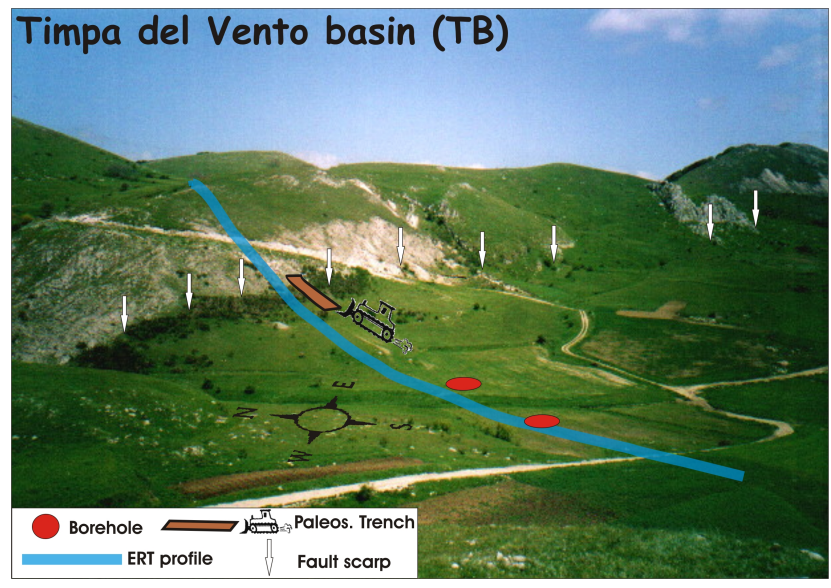

Fig. 2. Timpa del Vento basin (location in Fig. 1). This figure shows the ubication of the ERT profile, boreholes and trench surveys.

composed by two en-echelon main strands, showing a right step south of the Caggiano village (Fig. 1) (Galli et al., 2006).

Along the western border of the Timpe del Vento basin, the $\mathrm{CF}$ has been investigated by a large-scale ERT, followed by paleoseismological trenching (Fig. 2). The ERT survey has been carried out across the CF, using a 32-multichannel acquisition system with $10 \mathrm{~m}$ electrode spacing and about $50 \mathrm{~m}$ of investigation depth.

The electrical image, obtained after 5 iterations with an Abs. error of $5.8 \%$ (Fig. 3), shows a relatively strong variability of the electrical resistivity values, from about $5 \mathrm{ohm} * \mathrm{~m}$ (Pliocene sand-clay found in boreholes data; unit 9) to more than $1000 \mathrm{ohm} * \mathrm{~m}$ (pre-Quaternary carbonate bedrock; unit 10). In Fig. 4 the behaviour of the Abs error versus the number of iterations is reported. At about $90 \mathrm{~m}$, the ERT shows a sharp lateral variation of resistivity which fits with the fault plane observed both in the trench and in the field. Thus, the ERT result evidences clearly the dip of the fault in depth $\left(\sim 75^{\circ}\right.$ dip $)$, the wedge of the recent sediments (sector W in Fig. 3a with resistivity $>160 \mathrm{ohm} * \mathrm{~m}$ ) and a gentle tilting of the top surface of the carbonate bedrock towards the fault in the hanging wall itself.

As a matter of facts, paleoseismological analysis evidenced the recent activity of this strand of CF (Galli et al., 2006), which ruptured twice in the past millennium.

\subsection{Ufita Valley (Southern Apennine, Italy)}

The Ufita River Valley is located in Irpinia area, in the axial zone of the Southern Apennines in Italy (Fig. 5). Irpinia is one of the most active seismic area of Italy, with the highest seismic moment release, and has experienced several destructive earthquakes with maximum intensity Imax $\geq 10$ MCS (Mercalli, Cancani, Sieberg scale). The Ufita River Valley is located NW of the epicentral region of the 1980 Irpinia earthquake $(\mathrm{Mw}=6.9)$, and it was the epicentral 


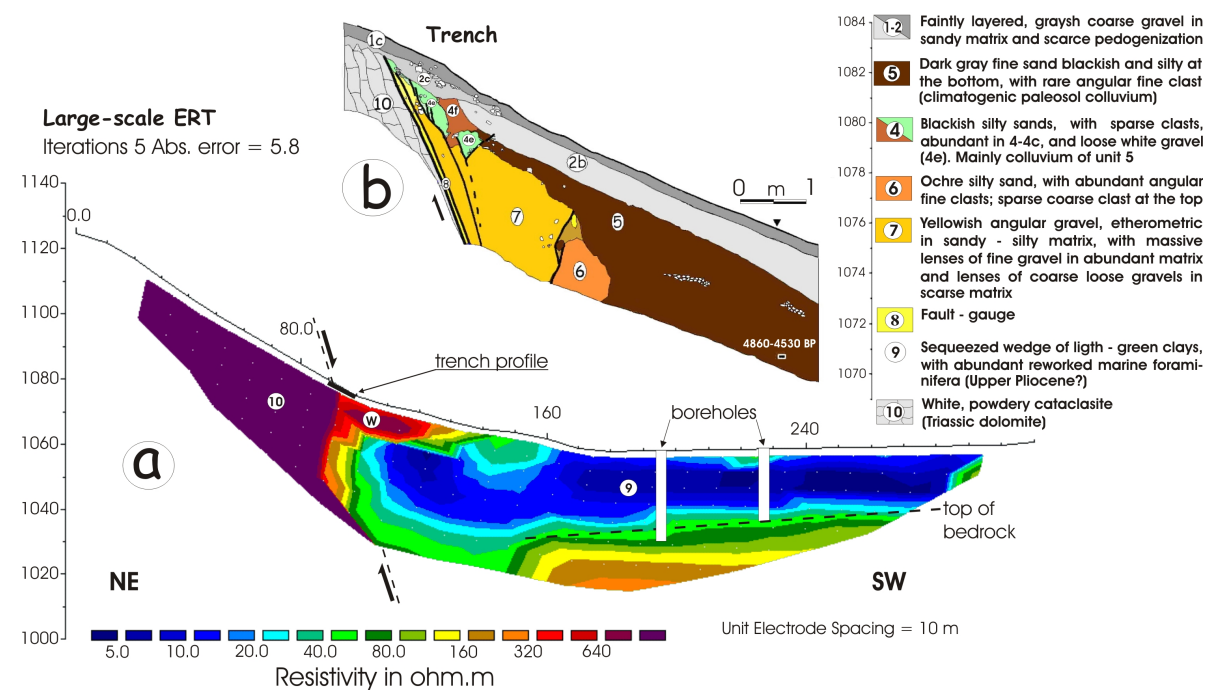

Fig. 3. (a) ERT carried out in the Timpa del Vento basin across the CF; (b) Paleoseismological trench excavated across the CF; (W) moderate-resistivity wedge (units from 1 to 9 in the paleoseismological trench) (modified from Galli et al., 2006).

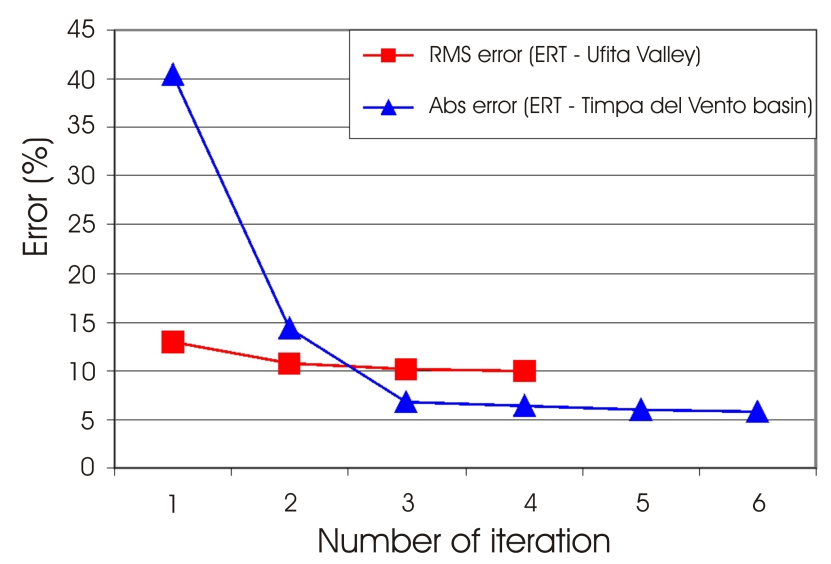

Fig. 4. RMS and Abs errors versus the number of iterations.

area of the 1732 earthquake $(\mathrm{Mw}=6.6$; Working Group CPTI, 2004).

According to several authors (Brancaccio et al., 1981, 1984; Basso et al., 1996), the NE border of the Valley is controlled by a NW-SE normal fault, evidenced also by a set of triangular facets along the hillside. Cinque et al. (2000) indicate a fault length of $22 \mathrm{~km}$, with a vertical slip rate of $0.2 \mathrm{~mm} / \mathrm{yr}$ in the last glacial maximum (LGM). It was also hypothesised that this fault was responsible for some of the largest earthquake of the region, as the $1694(\mathrm{Mw}=6.9$; Galli et al., 2006), and/or the 1732 ( $\mathrm{Mw}=6.6$; Meletti et al., 2000) events.

Across the Ufita Valley a $3560 \mathrm{~m}$ long deep ERT profile (red line in Fig. 5) was carried out in order to explore the geometry of the deeper sector of the basin. The deep ERT profile was obtained joining 11 roll-along multielectrode ac-

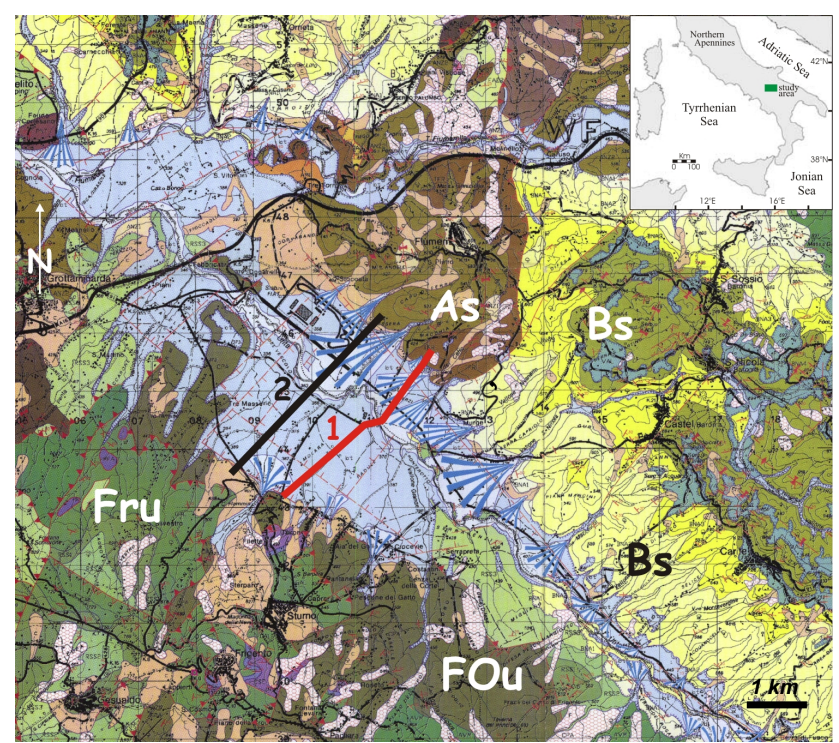

Fig. 5. Geological map of the study area in which are reported the deep ERT (1) and the geological section (2) profiles. FOu: Fortore Unit; Fru: Frigento Unit; As: Altavilla supersynthem; Bs: Baronia synthem (modified from Basso et al., 2002).

quisition system ( 48 channels -179 electrodes) with a minimum electrode spacing of $20 \mathrm{~m}$ and a maximum of $100 \mathrm{~m}$. An investigation depth of about $170 \mathrm{~m}$ was reached and about 5000 resistivity data were acquired (Fig. 6). The electrical model shows a variability of the resistivity values, from 3 to more than $90 \mathrm{ohm} * \mathrm{~m}$, and a RMS error of $12.9 \%$ after one iteration. The choice to stop the data inversion procedure at the result of the first iteration is due to the unchanged value of RMS error in the next iterations (Fig. 4). 


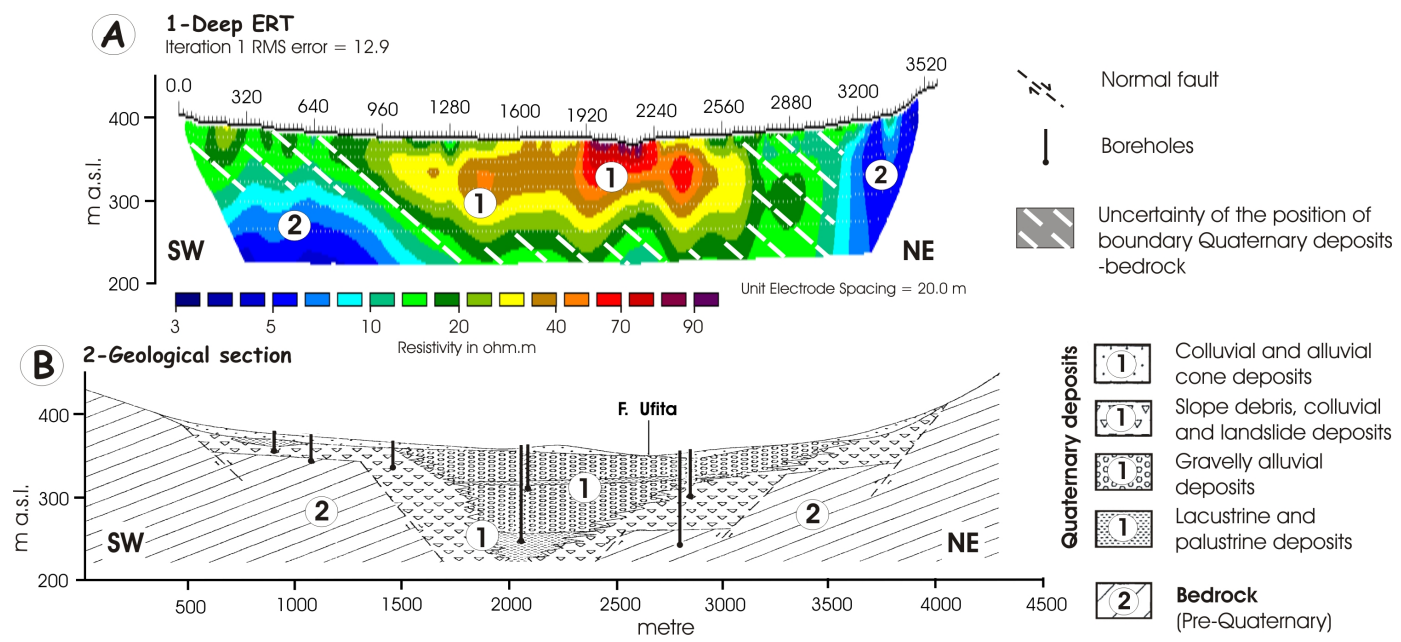

Fig. 6. (a) Deep ERT carried out along the profile 1; (b) Geological cross-section carried out along the profile 2 (Basso et al., 1996). The resistivity and geology models have the same metrics scale (modified from Giocoli et al., 2008).

Therefore, the resistivity values lower than $20 \mathrm{ohm} * \mathrm{~m}$ are related to the bedrock (number 2 in Fig. 6), while the resistivity values higher than $20 \mathrm{ohm}^{*} \mathrm{~m}$ are associated to the fluvial Quaternary deposits (number 1 in Fig. 6). Thus, the obtained resistivity model across the Ufita Valley puts in evidence a thickening of the Quaternary deposits, more than $150 \mathrm{~m}$ below the ground surface, toward the valley axial area. The south-western bedrock horizon appears smoother than in the north-eastern part. Moreover, the deep ERT shows a thick fluvio-lacustrine deposit slightly asymmetric towards NE (Giocoli et al., 2008).

The deep resistivity model has significant similarity with a geological section crossing the Valley (profile number 2 in Fig. 5), performed by Basso et al. (1996), in terms both of thickness and geometry of the sedimentary body, especially where the geological cross-section was constrained by deep borehole data (Fig. 6b).

\section{Conclusions}

The ERT method has been applied in two seismogenic areas in order to investigate the deep structural setting of Ufita Valley and one of the strand of the active Caggiano Fault (Galli et al., 2006; Timpa del Vento basin). The 2-D inverted ERT models have been correlated with data coming from geological and geomorphological survey, trenching and boreholes, showing a good fit. Our results show that the ERT method may be a useful tool to image active fault and geological setting in seismogenic areas with complex geology. In particular, in the lack of clear morphological indication, ERT allows to evidence the location of active faults at surface, providing also information of the fault geometry (dip, vertical displacement). In the Timpa del Vento case, ERT allowed also to distinguish some sedimentary units related to surface ruptures, their shape and thickness (i.e., colluvial wedges), giving a valuable support for the choice of the best location for paleoseismological trenching. In the Ufita Valley, the ERT shows that the dimension and geometry of the basin potentially associated to the so-called Ufita Fault is not scaled to the size of fault itself. If this is true, we might speculate that the triangular facets may be just geomorphic features related to the linear erosion process of the Ufita River and of its right tributaries.

Acknowledgements. Part of this activity research has been funded by the seismological projects $\mathrm{S} 2$, by the Italian Dipartimento della Protezione Civile and Istituto Nazionale di Geofisica e Vulcanologia.

Edited by: F. Soldovieri

Reviewed by: two anonymous referees

\section{References}

Basso, C., Di Nocera, S., Matano, F., and Torre, M.: Alcune osservazioni di geologia del Quaternario nell'alta valle del Fiume Ufita (Appennino Irpino, Italia meridionale), Il Quaternario, 9(1), 309-314, 1996.

Basso, C., Ciampo, G., Ciancia, S., Di Nocera, S., Matano, F., and Torre, M.: Geologia del settore Irpino-Dauno dell'Appennino meridionale: unità meso-cenozoiche e vincoli stratigrafici nell'evoluzione tettonica Mio-Pliocenica, Studi Geologici Camerti, Nuova Serie 2, 7-27, 2002.

Caputo, R., Piscitelli, S., Oliveto, A., Rizzo, E., and Lapenna, V.: The use of electrical resistivity tomographies in active tectonics: examples from the Tyrnavos Basin, Greece, J. Geodyn., 36, 1935, 2003.

Demanet, D., Pirard, E., Renardy, F., and Jongmans, D.: Application and processing of geophysical images for mapping faults, Computers and Geosciences, 27, 1031-1037, 2001. 
Diaferia I, Barchi, M., Loddo, M., Schiavone, D., and Siniscalchi, A.: Detailed imaging of tectonic structures by multiscale earth resistivity tomographies: the Colfiorito normal faults (Central Italy), Geophys. Res. Lett., 33, L09305, doi:10.1029/2006GL025828, 2006.

Galli, P., Bosi, V., Piscitelli, S., Giocoli, A., and Scionti, V.: Late Holocene earthquakes in southern Apennines: paleoseismology of the Caggiano fault, Int. J. Earth Sci., 95(5), 855-870, 2006.

Giocoli, A., Magrì, C., Vannoli, P., Piscitelli, S., Rizzo, E., Siniscalchi, A., Burrato, P., Basso, C., and Di Nocera, S.: Electrical resistivity tomography investigations in the Ufita valley (southern Italy), Ann. Geophys., in press, 2008.

Loke, M. H.: Tutorial: 2-D and 3-D electrical imaging surveys. I: Course notes for USGS workshop "2-D and 3-D inversion and modelling of surface and borehole resistivity data", Storrs, CT, 13-16, 2001.

Loke, M. H. and Barker, R.D.: Rapid least-squares inversion of apparent resistivity pseudosections by a quasi-newton method, Goephys. Prospect., 44, 131-152, 1996.

Nguyen, F., Garambois, S., Chardon, D., Jongmans, D., Bellier, O., and Hermitte, D.: Slow active fault detection and imaging using multiple geophysical methods: the Trévaresse thrust (Provence, France), Geophys. Res. Abstracts, 5, 10878, ISSN Print:1029_ 7006, ISSN Eletronic: 1607-7962, 2003.
Nguyen, F., Garambois, S., Jongmans, D., Pirard, E., and Loke, M. H.: Image processing of 2-D resistivity data for imaging faults, J. Appl. Geophys., 57, 260-277, 2005.

Rizzo, E., Colella, A., Lapenna, V., and Piscitelli, S.: Highresolution images of the fault-controlled High Agri Valley basin (Southern Italy) with deep and shallow electrical resistivity tomographies, Phys. Chem. Earth, 29, 321-327, 2004.

Storz, H., Storz, W., and Jacobs, F.: Electrical resistivity tomography to investigate geological structures of the earth's upper crust, Geophys. Prospect., 48, 455-471, 2000.

Suzuki, K., Toda, S., Kusunoki, K., Fujimitsu, Y., Mogi, T., and Jomori, A.: Case studies of electrical and electromagnetic methods applied to mapping active faults beneath the thick quaternary, Eng. Geol., 56, 29-45, 2000.

Wise, D. J, Cassidy, J., and Locke, C.A.: Geophysical imaging of the Quaternary Wairoa North Fault, New Zealand: a case study, J. Appl. Geophys., 53, 1-16, 2003.

Working Group CPTI: Catalogo parametrico dei terremoti italiani, versione 2004 (CPTI04), INGV, Bologna, Available on line from: http://emidius.mi.ingv.it/CPTI04, 2004. 